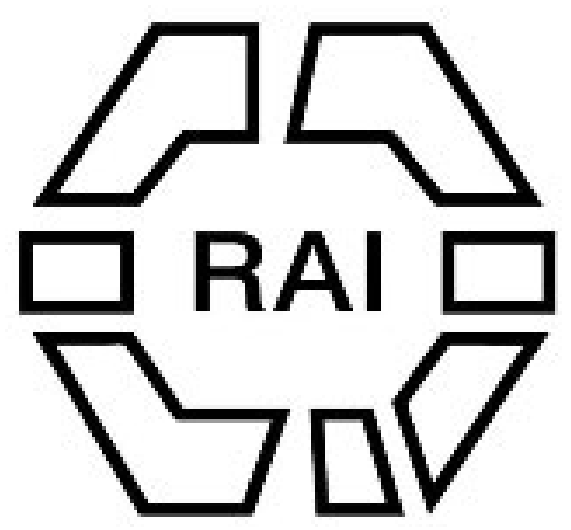

A Last Contribution to Scottish Ethnology

Author(s): John Beddoe

Source: The Journal of the Royal Anthropological Institute of Great Britain and Ireland, Vol. 38 (Jan. - Jun., 1908), pp. 212-220

Published by: Royal Anthropological Institute of Great Britain and Ireland

Stable URL: http://www.jstor.org/stable/2843134

Accessed: 28/06/2014 15:19

Your use of the JSTOR archive indicates your acceptance of the Terms \& Conditions of Use, available at http://www.jstor.org/page/info/about/policies/terms.jsp

JSTOR is a not-for-profit service that helps scholars, researchers, and students discover, use, and build upon a wide range of content in a trusted digital archive. We use information technology and tools to increase productivity and facilitate new forms of scholarship. For more information about JSTOR, please contact support@jstor.org. 


\title{
A LAST CONTRIBUTION TO SCOTTISH ETHNOLOGY.
}

\author{
By John Beddoe, M.D., LL.D., F.R.S.
}

\section{[With Plate XVIII.]}

I PROPOSE a little consideration of the progress of Scottish Ethnology, before entering on any criticism of Mr. Gray's valuable paper (Journ. Roy. Anthrop. Inst., xxxvii, p. 375).

Fifty-five years ago, when I brought out my Contribution to Scottish Ethnology, there were others already engaged in laying the foundations of the subject. Daniel Wilson had anticipated the theory of the succession of Neolithic dolicocephali and bronze brachys, which Thurnam afterwards elaborated; and Arthur Mitchell had studied the physiognomies of Northern Scotland, and carefully marked out three leading types. My observations showed the preponderance of light eyes with dark hair on the western, and of light eyes with light hair on the eastern, and especially the south-eastern, side of the country, with an increase of dark shades in the towns.

Next in order (in 1870) came my collections for the Stature and Bulk of Man in the British Isles, printed in the Anthropological Memoirs, vol. iii. Among the reports sent in to me were many of great value; and some of those from lunatic asylums were by distinguished men, such as Sibbald, Aitken, Howden, Grierson, Lindsay. Noteworthy deductions were the great stature in the Merse, Upper Galloway and Kyle, the inferiority of lunatics to the general population, the physical degeneration in the great towns. These are more or less confirmed by Mr. Tocher's recent observations on the insane.

Next in order came the observations on the West Highlanders, respecting stature, colour and craniometry, contained in my Races of Britain, 1885. The chief points were the good stature, $1727 \mathrm{~mm}$., the preponderance of light eyes and dark hair, the large size and low breadth index $(76 \cdot 27)$ of the head.

Next followed an important advance due to Sir Wm. Turner, who, dealing with a large quantity of material, showed the hitherto unknown frequency of brachycephaly in modern skulls from such districts as East Lothian and Fife, but not, apparently, in the west.

On Mr. Tocher's statistics of the insane, published by the Henderson Trust, I have already commented. 'They agree with mine of forty years ago in indicating a higher stature in Argyle and in the Border Country than elsewhere. He also agrees with me in showing a low cephalic index for Argyle, while over the whole north of Scotland his indices are high for Britain, 78 or more. His mean stature for the whole of his material is lower even than mine (65.86 inches or $1673 \mathrm{~mm}$.), mine being 66.62 inches or $1692 \mathrm{~mm}$.; but this difference probably arises not so 
much from a real fall in average stature during the last generation, as from the fact that my directions to my helpers excluded idiots, persons not in good bodily health, and those under twenty-three or over fifty years of age, whereas his did not.

I come now to the latest contribution to our subject, the pigmentation survey of Mr. John Gray and Mr. Tocher.

The method of collecting the facts, viz., the colours of the hair and eyes in all or most of the school children of Scotland, left, I think, little to be desired; though Mr. Gray rightly regrets that standard colour-cards could not be used, owing to the failure of the people employed to produce sufficiently accurate ones. Many attempts have been made in former years to produce such cards, in fact all of us, from Broca downwards, who have been interested in the subject, have tried our hands on such attempts ; for example, General Pitt Rivers made an endeavour, and took great pains about it; but the result was a lamentable failure. The tints were flat, and flat tints cannot represent hair. I tried stripes without satisfying myself. The only man who has ever been moderately successful has been Topinard, who collected and arranged his material for all France with the assistance of irregularly striped and coloured diagrams, which, however, represented only the median tints (our brown, the French chatain clair, the German hellbraun); he also designed representations of the median hues of eyes, dark grey, pale ashy brown, hazel-grey, light fawn and green. With these one can produce tolerably trustworthy indices of nigrescence of both hair and eyes.

It is as impossible, however, entirely to get rid of the personal equation as it is to command the weather. Sunshine or shade, clear or dull sky, indoor or outdoor observation, must always affect our judgment of colour, which, one needs to remind oneself sometimes, is not an intrinsic quality of objects. ${ }^{1}$ But internal evidence leads me to appreciate highly the work of these Scottish schoolmasters, from this point of view.

Among the numerous small difficulties with which one has to contend in this kind of quest, is that of correctly correlating the hair-colour of boys and of girls, the former generally short-cropt and neglected, the latter long, outspread, combed, often washèd. Exposure to water, especially soapy water, sun and air, tends to bleach the tips and surface at least of the hair. Natural sexual differences of this kind have not been very much studied; but my own observations point to greater pigmentation of eye, if not of hair also, among females in Great Britain, and Havelock Ellis (Man and Woman, pp. 224-228) adduces a good deal of evidence to the same effect from other countries. The Scotch schoolmasters find no great difference on the whole, 22.81 per cent. of dark eyes in the girls to 22.31 in the boys, and 26.57 of dark hair to $26 \cdot 27$. There are several districts (e.g., Midlothian, Sutherland, Dunfermline) where the hair of the girls comes out much lighter than that of the boys, and a few (e.g., Islay, etc., Nithsdale, Kirkcaldy town) where

1 Topinard's standards are for use in bright sunlight. Their employment in Scotland would yield too many blonds. 
their hair is lighter and their eyes are darker. Mr. Gray, a strong believer in sexual heredity, seems to think that Queen Margaret may have brought the fair Saxon ancestresses of the Dunfermline girls from England with her. I am more disposed to think that the matrons of "grey Dunfermline " washed their daughters" hair preparatory to the inspection, especially when I note that the eye-index of the boys and girls is identical. It is perhaps to be regretted that Mr. Gray did not affix anything beyond mere ordinal numbers to his 110 or, more accurately, 102 districts, as a means of identification. In a large number of cases, in a majority indeed, their boundaries do not correspond with those of counties or other wellknown divisions, and as laid down in the map are not strictly accurate. Though I am probably as well acquainted with Scottish topography as most Englishmen, I cannot positively identify some of these districts, especially the small ones. around Glasgow, and in the tables which I have drawn out from Mr. Tocher's figures I have been obliged to trust to, and cite, the numerals alone in several cases.

The inclusion of jet black among the categories of hair-colour is fully justified by the results of this census. The personal equation may interfere here as elsewhere, but less often than in the cases of "red" and "fair," for example, in which the boundary is less distinct, and error is easy. The average of jet black hair in Scotch children is set down at about 1.2 per cent. in both sexes; but I find over 2 per cent. reckoned in fifteen districts. In three of these this proportion is reached in boys only, though there is a considerable but smaller excess in the girls also. These are Nos. 55 and 56, East Fife; 95, East Ross; and 90, Lower Moray.' In five it occurs in girls only, these being 59, Stirlingshire, Menteith, etc. ; 93, 94, Beauly and Lochness ; 103, Arran and Kintyre ; 107, Uist ; and 108, Lewis. and Harris. 'The seven in which both sexes present this great excess of jet black are 70, 71, Athol and Breadalbane; 91, Strathspey; 99, Skye, W. Ross, Glenelg; 100, Mull, Morven, etc. ; 97, Caithness East Coast; 70, Gowrie ; and 18 (probably the town of Paisley). It will be seen that with the exception of the longurbanized Paisley, and of East Fife, an ancient seat of foreign commerce, the whole fifteen are either within, or astride of, the Highland frontier. Except Paisley, there is not a single instance south of the Forth, nor one between the Spey and the Firth of Tay,

Surely there is something "racial" here. Jet black hair does not readily develop, it would seem, from urban selection; otherwise Paisley would not stand alone as a town in our list. It belongs apparently to the Gael, but not to the Scots of Dalriada alone, but also to the eastern and northern Gael, ${ }^{1}$ who are at. least partly of Pictish descent. It does not, however, seem to be conspicuous in Mr. Gray's Galwegians, who were the only Picts still known as such in the middleages, and who still rank as dark haired both with him and with me.

I cannot understand under what curious misconception Mr. Gray can be lying, when he says (p. 384) that "black hair is not stated in a separate category Gaelic.

1 i.e., the excess of black hair is common to the speakers of all three dialects of Scottish 
by European observers," and (p. 385) that "there are no data" (as to black hair) "for comparison with other countries." So far from this being the case, there is scarcely a European observer of children's colours who does not make black a separate category. Virchow in Germany, Georg Mayr in Bavaria, Schimmer in Austria, Majer and Kopernicki in Poland, Kollmann in Switzerland, have all done so. So did Vanderkindere in Belgium, but as I have elsewhere ${ }^{1}$ pointed out, his observers included many dark browns under black (noir) just as Virchow's included under blue eyes our blue-greys if not even some light greys, so vitiating comparisons. Livi and Retzius and Fürst all employed a black category, but as they worked on young adults their results are not comparable with Gray's.

The modern biometrical school seems to be bent on upsetting our most cherished prejudices. And Mr. Gray, on the strength of an observation in the fashionable county of Dorset, says that "it is probable that there is not much difference between the percentages of red hair in Scotland and in England"; whereas we were accustomed to suppose that, barring perhaps the Votiaks and one or two other such remote tribes, the Scots were the most rufous folk in existence. In fact-not to quote my own pretty numerous observations-the military statistics of young male adults give, for Scotland, 4.7 per cent. of red hair; for Ireland, 4.5 ; for Wales, 4.4 ; and for England, 3.5 per cent. ${ }^{2}$ There is little in Holland (1.81) and not much in Flanders (2.18); but in Westphalia and other parts of the old Saxon land I found as much as 3.8 per cent. The German red, however, usually verges on pale yellow; and the great unpopularity of the colour in Germany led to its being almost ignored by Virchow's schoolmaster-agents.

I have constructed a map to illustrate the tables into which I have boiled down those of Messrs. Gray and Tocher. It is based on the Compound Index of Nigrescence, which is gotten by adding the index of the eyes to twice the index of the hair; this is done with the object of attributing greater weight to the more important characteristic: But I have also inserted the original Index of Nigrescence, which represents the hair only, and is gotten by subtracting the red + the fair from the dark + twice the black. It is generally positive in England and Scotland, and almost always in Ireland. The eye-index, also inserted, is gotten by subtracting the light, including blue, blue-grey, and light grey, from the brown or dark, neglecting, as in the case of the hair, the median hues: in Scotch children this is always a minus quantity, as is also the compound index.

I think it will be acknowledged that the racial indications of Messrs. Gray and Tocher's figures are most simply and clearly developed by my map and tables. Probable influences of climate, if they exist at all, are indistinct. The west and south-west of Scotland are warmer, no doubt, than the east and north-east, and also wetter and perhaps less sunshiny, and they furnish the largest proportions of dark hair. But racial and historical causes will account for most of the phenomena,

1 In my Huxley lecture on "Colour and Race" (Journ. Anthrop. Inst., xxxv, 1905, p. 219).

2 Races of Britain, pp. 190-193. In the north of England the percentage is higher, in the south lower than this. 
(among which is the fact that most of the fairest districts lie well towards the south) while urban selection may be appealed to for an explanation of the rest.

The indications are that the earlier pre-Anglian population was generally dark in hair and light in eye, though it spoke two if not three different languages, and though there may have been differences in prevailing types corresponding thereto to some extent.

It would be of great interest if we could make out a surviving type for the Strathclyde Walenses, who were still distinguishable from Scots, Picts and Angles, in the earlier middle ages. But the place-names in Strathclyde and its neighbourhood do not help us much; and the Welsh were probably Anglicised before the general adoption of surnames. ${ }^{1}$ The range of hills that separates Lanarkshire from Ayrshire would probably be the best hunting ground for traces of them, and perhaps Lesmahagow and Douglasdale would repay investigation.

I have made an endeavour to divide most part of Scotland into several ethnological provinces, using Mr. Gray's data, and averaging the divers indices of the several districts included in each province. This method is not arithmetically accurate, of course, but it is sufficiently so for my purpose.

\begin{tabular}{|c|c|c|c|c|c|}
\hline \multirow{2}{*}{ Provinces. } & & \multirow{2}{*}{$\begin{array}{l}\text { No. of } \\
\text { districts. }\end{array}$} & \multicolumn{2}{|c|}{ Indices of } & \multirow{2}{*}{$\begin{array}{l}\text { Compound } \\
\text { index. }\end{array}$} \\
\hline & & & Hair. & Eyes. & \\
\hline $\begin{array}{ll}\text { Anglian } \ldots & \ldots \\
\text { N.E. Lowlands } & \ldots \\
\text { Fife, etc. ... } & \ldots \\
\text { Norse (more or less) } \\
\text { Clydesdale } & \ldots \\
\text { East Highland } & \ldots \\
\text { Galloway... } & \ldots \\
\text { West Highland } & \end{array}$ & $\begin{array}{c}\ldots \\
\ldots \\
\ldots \\
\ldots \\
\ldots \\
\ldots \\
\ldots \\
\ldots\end{array}$ & $\begin{array}{r}7 \\
10 \\
6 \\
6 \\
12 \\
4 \\
3 \\
6\end{array}$ & $\begin{array}{l}-10.7 \\
-\quad 8 \cdot 4 \\
-\quad 7 \cdot 9 \\
-\quad 6.7 \\
-6.1 \\
-1 \cdot 4 \\
-1 \cdot 1 \\
+\quad 2.5\end{array}$ & $\begin{array}{l}-25 \cdot 6 \\
-24 \cdot 5 \\
-21 \cdot 6 \\
-23 \cdot 3 \\
-24 \cdot \\
-29 \cdot 9 \\
-23 \cdot 1 \\
-27 \cdot 5\end{array}$ & $\begin{array}{l}-47 \\
-41 \cdot 3 \\
-37 \cdot 4 \\
-36 \cdot 7 \\
-36 \cdot 2 \\
-32 \cdot 7 \\
-25 \cdot 4 \\
-22 \cdot 5\end{array}$ \\
\hline Towns & $\ldots$ & 20 & -1.38 & $-19 \cdot 8$ & $-22 \cdot 5$ \\
\hline ScOTLAND .. & $\ldots$ & & $-3 \cdot 84$ & $-22 \cdot 5$ & $-30 \cdot 2$ \\
\hline
\end{tabular}

The provinces are here arranged in the order of lightness of both eyes and hair; but it will be observed that the order of index of hair, taken singly, almost exactly corresponds, whereas the index of eye-colour runs irregularly, and is largest in the Highlands. I have excluded from my province of Clydesdale, whose limits are those of Mr. J. A. H. Murray's dialect map, the populous districts around Glasgow, as having been foci of recent immigration and perhaps, too, areas of some forms of selection. There is nothing clearly distinctive about the Clydesdale figures-just a trifle more darkness of hair and lightness of eye than

1 The distinguished surname of Pringle (Hopringle or Ap-pringle) is claimed as Welsh ; but I know of no other presumably Welsh patronymic in southern Scotland. 
in the means for all Scotland. Two considerations occur to me, first, that the Kymric Kelts in Scotland simply overlay the Gaels, and, though they changed the language, may not have much affected the physical type ; and second, that, judging from the place-names and what of local history remains, it is likely enough that at one time and another considerable waves of Anglian colonization may have overflowed Lanarkshire and Kyle and Cunningham; the last district, by the way, actually bears an English name. And such waves may have lightened the colours in places, without much affecting the cranial or facial types.

Various lines of probability, among which these statistics of Mr. Gray's may be reckoned, combine to show that the native Keltic or Pictish population of the north-eastern Lowlands was gradually and almost wholly swamped by Flemish, Norse and Saxon settlers. Yet an ordinary map shows us comparatively few local names there that are not Keltic, fewer indeed, as I think, than in Clydesdale where such places as Dolphinton, and Symington and Eglinton bear witness to the settlements and their leaders.

Another district, interesting by reason of its very dark colours, is No. 95 of Gray, which apparently includes parts of the Munros' and Rosses' countries, and the south-east coast of Sutherland county. It may be considered in conjunction with 97 and 98, the two divisions of Caithness, which unfortunately have not been arranged to correspond with the boundary of the languages. Had they been so, perhaps we might have detected an ethnic difference between the eastern Norsemen and the western Gaels, ${ }^{1}$ which, as it is, does not come out. Mr. Gray's 97 includes the long seaboard stretch of the Gaelic parish of Latheron; and though there are both Norse place-names and Norse surnames in that parish, all the Latheron men whom I have seen (and they have not been very few) have had dark or black hair. ${ }^{2}$ Again, in east Ross and south-east Sutherland, such place.names as Tain and Dingwall, and Brora and Helmsdale, indicate a ruling population at least of Scandinavians; and though the clans Munro and Ross were probably purely Keltic, and the former is even derived by an untrustworthy tradition from Ireland, the names of the MacIvors and Gunns sound otherwise. These little districts deserve more minute study, which I hope Mr. Gray will be able and willing to give to them. He must have in his possession, and capable of separate analysis, the material for such districts as the Norwegian Butt of Lewis, where, as a native once told me, "there was something almost disreputable about dark hair," for Harris, or for the islands of Colonsay, Barra, Iona, Lismore, Jura, Seal, and Luing; or for such elevated villages as Castleton of Braemar, Wanlockhead, and Leadhills; for Coningsburgh in Shetland, or for that abode of giants Balmaclellan in Upper Galloway.

1 See return from Forss in my Stature and Bull in which it is well marked.

2 The Norsemen often brought their thralls with them ; and these might be of Finnish, or Irish or other alien blood, and may probably have been often brachycephalic as is the case in South-western Norway at this day. 
Table Indicating Order of Coloration in Mr. Gray's Districts of Scotland, FROM his own Data.

\begin{tabular}{|c|c|c|c|c|}
\hline & & $\begin{array}{c}\text { Index of } \\
\text { Nigrescence, } \\
\text { hair. }\end{array}$ & $\begin{array}{l}\text { Index of } \\
\text { Nigrescence, } \\
\text { eyes. }\end{array}$ & $\begin{array}{l}\text { Compound } \\
\text { index. }\end{array}$ \\
\hline 64 & Arbroath $\quad \ldots$ & $+2 \cdot 6$ & $-11 \cdot 5$ & -6.3 \\
\hline 95 & $\begin{array}{l}\text { East Ross and East } \\
\text { Sutherland. }\end{array}$ & $+5 \cdot 6$ & $-23 \cdot 4$ & $-12 \cdot 1$ \\
\hline 50 & $\begin{array}{lll}\text { Kirkcaldy } \quad \ldots . & \text {.. }\end{array}$ & +0.9 & $-14: 3$ & $-12 \cdot 5$ \\
\hline 13 & Glasgow $\quad \ldots$ & +2 & $-18 \cdot 3$ & $-14: 3$ \\
\hline 24 & Greenock $\quad \ldots$ & +26 & $-20 \cdot 5$ & $-15 \cdot 3$ \\
\hline 81 & Peterhead $\quad \ldots$ & 0 & $-15 \cdot 4$ & $-15 \cdot 4$ \\
\hline 63 & Ealkirk $\quad \ldots$ & $+1 \cdot 8$ & $-20 \cdot 7$ & -17 \\
\hline 31 & Carrick $\quad \ldots$ & -0.3 & $-18 \cdot 7$ & $-19 \cdot 3$ \\
\hline 66 & Dundee town & -0.9 & $-17 \cdot 8$ & $-19 \cdot 6$ \\
\hline 62 & Denny $\quad \ldots$ & +0.85 & $-20 \cdot 5$ & $-19 \cdot 7$ \\
\hline 92 & Inverness town & +1.5 & $-22 \cdot 8$ & $-19 \cdot 8$ \\
\hline 60 & Stirling town & $-1 \cdot 8$ & $-16 \cdot 7$ & $-20 \cdot 2$ \\
\hline 98 & Caithness, inner $\quad .$. & -0.3 & $-19 \cdot 9$ & $-20 \cdot 5$ \\
\hline 103 & Arran and Kintyre .. & $+1 \cdot 6$ & -24 & $-20 \cdot 8$ \\
\hline 104 & Bute, etc. '... & $+0 \cdot 1$ & $-21 \cdot 5$ & $-21 \cdot 3$ \\
\hline $\left.\begin{array}{l}11 \\
14\end{array}\right\}$ & E. and S. Glasgow & $-1 \cdot 0$ & $-19 \cdot 4$ & $-21 \cdot 4$ \\
\hline 101 & Lochaber $\quad \ldots$ & $+3 \cdot 1$ & $-27 \cdot 6$ & $-21 \cdot 4$ \\
\hline 100 & Mull, Morven, etc. .. & $+3 \cdot 6$ & $-29 \cdot 5$ & $-22 \cdot 3$ \\
\hline 58 & Strathearn $\quad \ldots \quad \ldots$ & $+1 \cdot 9$ & $-26 \cdot 3$ & $-22 \cdot 5$ \\
\hline 18 & Paisley town ... & $-1 \cdot 8$ & $-19 \cdot 7$ & $-23 \cdot 3$ \\
\hline 102 & Islay, Knapdale & $+5 \cdot 5$ & $-34 \cdot 6$ & $-23 \cdot 5$ \\
\hline 12 & Kirkintilloch... & $-1 \cdot 8$ & $-20 \cdot 6$ & $-24 \cdot 3$ \\
\hline 97\{ & $\begin{array}{ll}\text { Caithness } & \ldots \\
\text { East Coast } & \ldots\end{array}$ & -3.5 & $-17 \cdot 3$ & $-24 \cdot 3$ \\
\hline $\begin{array}{c}19, \\
20,22\}\end{array}$ & Partick Govan & $-2 \cdot 1$ & $-20 \cdot 2$ & $-24 \cdot 5$ \\
\hline 99 & Skye, Glenelg & $+1 \cdot 1$ & -27 & $-24 \cdot 7$ \\
\hline 107 & Uist $\ldots \quad \ldots$ & +2.5 & $-31 \cdot 4$ & $-26 \cdot 4$ \\
\hline 16 & S.W. Glasgow & $-3 \cdot 1$ & $-20 \cdot 3$ & -26.5 \\
\hline 17 & Renfrewshire, east & -0.8 & $-25 \cdot 3$ & -27 \\
\hline 86 & Banff, littoral & $-8 \cdot 2$ & $-10 \cdot 9$ & $-27 \cdot 4$ \\
\hline 57 & Fife, interior ... & $-5 \cdot 1$ & $-17 \cdot 4$ & $-27 \cdot 6$ \\
\hline $\left.\begin{array}{l}32 \\
33\end{array}\right\}$ & Wigtonshire ... & $-1 \cdot 1$ & -24 & $-26 \cdot 1$ \\
\hline No. 4 & & -26 & $-23 \cdot 2$ & $-28 \cdot 4$ \\
\hline 44 & Edinburgh city & $-4 \cdot 1$ & $-20 \cdot 1$ & $-28 \cdot 4$ \\
\hline 21 & W. Renfrewshire & $-3 \cdot 1$ & $-22 \cdot 4$ & $-28 \cdot 7$ \\
\hline $\begin{array}{l}71,76 \\
105\end{array}$ & Athol .. $\quad \ldots$ & $+0 \cdot 3$ & $-29 \cdot 7$ & $-29 \cdot 1$ \\
\hline 105 & Lennox, west... & $-1 \cdot 6$ & $-26 \cdot 3$ & $-29 \cdot 5$ \\
\hline
\end{tabular}




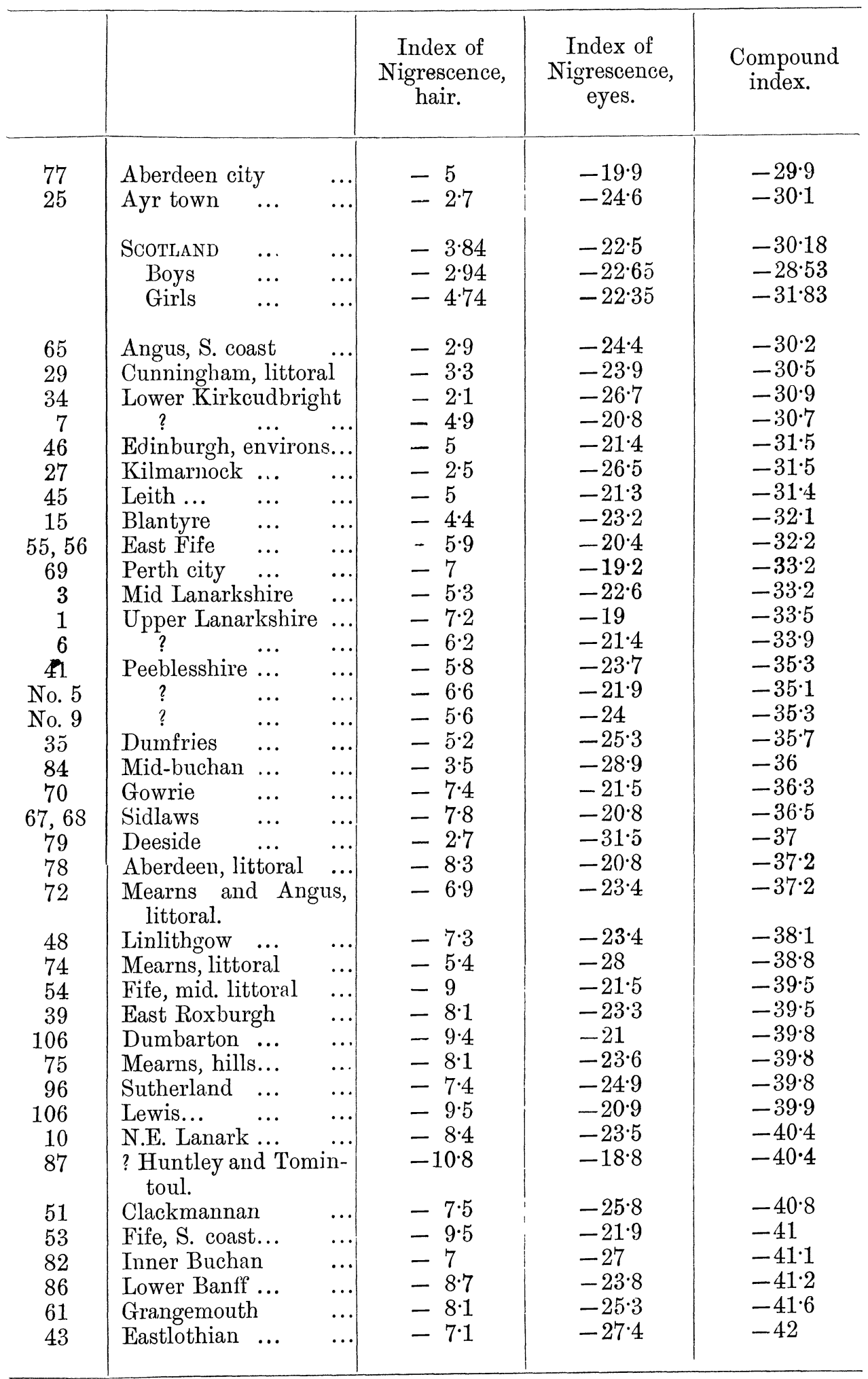




\begin{tabular}{|c|c|c|c|c|}
\hline & & $\begin{array}{c}\text { Index of } \\
\text { Nigrescence, } \\
\text { hair. }\end{array}$ & $\begin{array}{c}\text { Index of } \\
\text { Nigrescence, } \\
\text { eyes. }\end{array}$ & $\begin{array}{l}\text { Compound } \\
\text { index. }\end{array}$ \\
\hline $\begin{array}{c}89 \\
73 \\
52 \\
40 \\
59 \\
\\
91 \\
93,94 \\
36 \\
28 \\
83 \\
37 \\
90 \\
26 \\
110 \\
109 \\
88\end{array}$ & 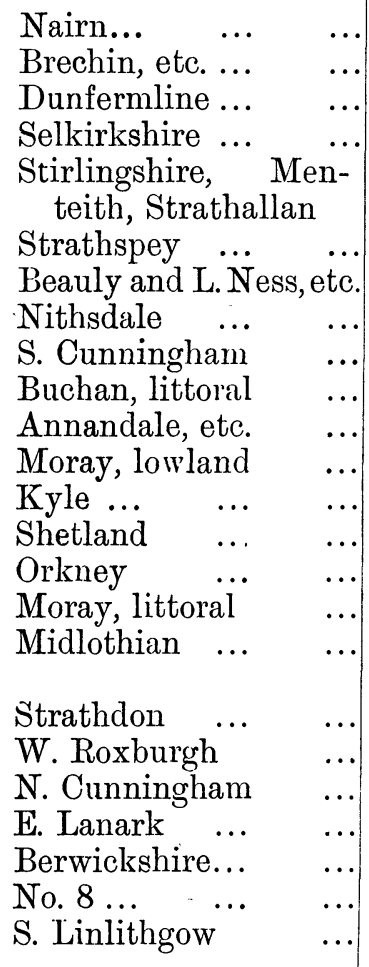 & $\begin{array}{l}-9 \cdot 6 \\
-7 \\
-10 \cdot 3 \\
-11 \cdot 6 \\
-5 \cdot 6 \\
-7 \cdot 6 \\
-4 \cdot 2 \\
-8 \cdot 5 \\
-8 \cdot 3 \\
-7 \cdot 9 \\
-10 \cdot 1 \\
-7 \cdot 7 \\
-10 \cdot 9 \\
-10 \cdot 7 \\
-8 \cdot 9 \\
-12 \cdot 1 \\
-11 \cdot 8 \\
-10 \cdot 1 \\
-13 \cdot 4 \\
-10 \cdot 1 \\
-16 \\
-12 \cdot 2 \\
-11 \cdot 4 \\
-14 \cdot 7\end{array}$ & $\begin{array}{l}-23 \cdot 2 \\
-28 \cdot 5 \\
-22 \cdot 9 \\
-20 \cdot 9 \\
-33 \cdot 2 \\
-29 \cdot 2 \\
-36 \cdot 1 \\
-27 \cdot 7 \\
-28 \cdot 2 \\
-29 \cdot 3 \\
-25 \cdot 2 \\
-30 \cdot 4 \\
-24 \cdot 9 \\
-26 \cdot 8 \\
-30 \cdot 3 \\
-24 \cdot 5 \\
-26 \cdot 3 \\
-31 \\
-24 \cdot 9 \\
-31 \cdot 9 \\
-21 \cdot 9 \\
-30 \cdot 3 \\
-33 \cdot 8 \\
-29 \cdot 6\end{array}$ & $\begin{array}{l}-42 \cdot 5 \\
-42 \cdot 5 \\
-43 \cdot 5 \\
-44 \cdot 1 \\
-44 \cdot 4 \\
-44 \cdot 4 \\
-44 \cdot 5 \\
-44 \cdot 8 \\
-44 \cdot 9 \\
-45 \cdot 2 \\
-45 \cdot 5 \\
-45 \cdot 8 \\
-46 \cdot 7 \\
-48 \cdot 2 \\
-48 \cdot 2 \\
-48 \cdot 8 \\
-49 \cdot 9 \\
-51 \cdot 2 \\
-51 \cdot 7 \\
-52 \cdot 2 \\
-54 \\
-54 \cdot 8 \\
-56 \cdot 7 \\
-59 \cdot 1\end{array}$ \\
\hline
\end{tabular}


Journal of the Royal Anthropological Institute, Vol. XXXVIII, 1908, Plate XVIII.

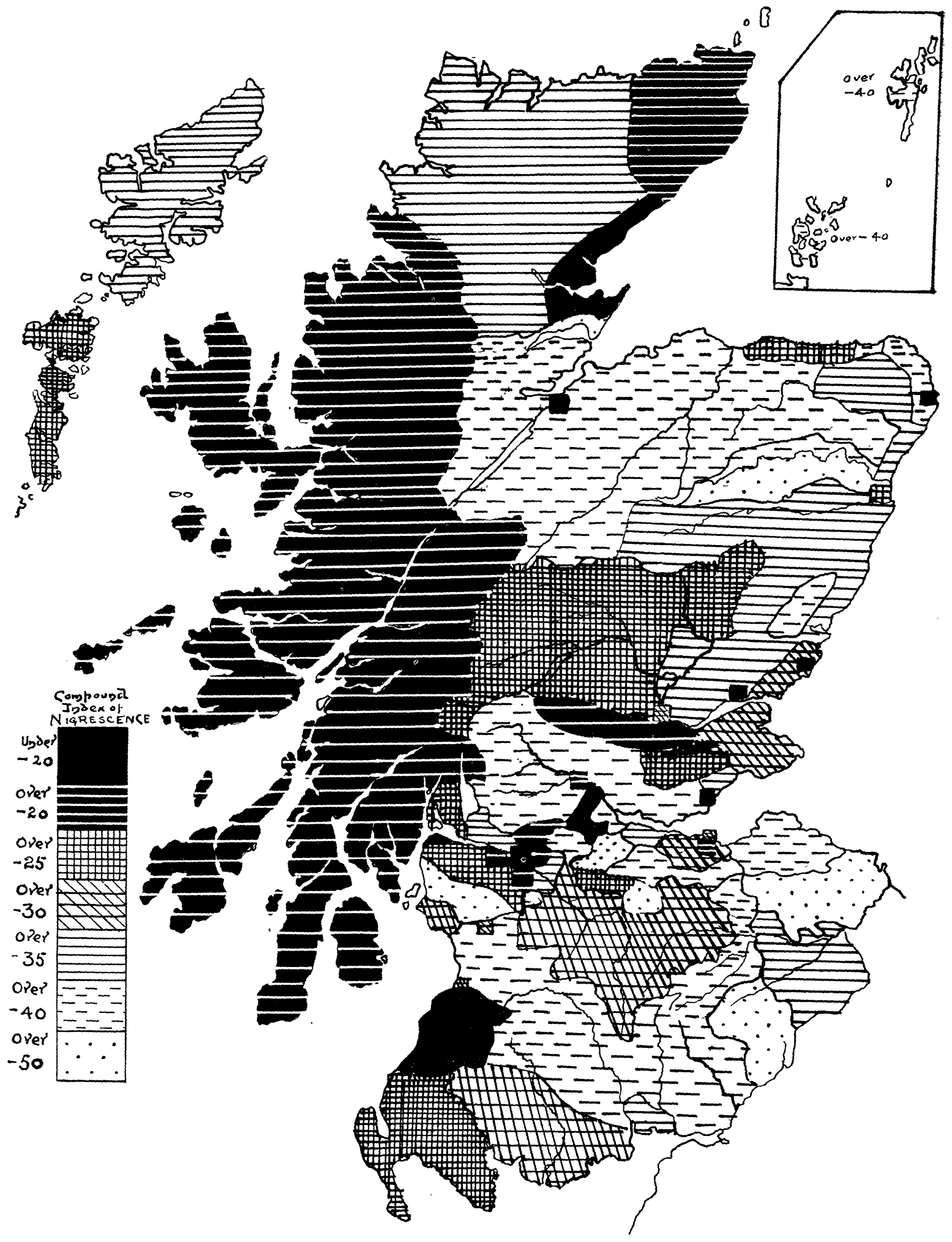

A LAST CONTRIBUTION TO SCOTTISH ETHNOLOGY. 